\begin{tabular}{|l|l|l||}
\hline \multicolumn{2}{|c|}{ PublisherInfo } \\
\hline \hline PublisherName & $:$ & BioMed Central \\
\hline \hline PublisherLocation & $:$ & London \\
\hline \hline PublisherImprintName & $:$ & BioMed Central \\
\hline \hline
\end{tabular}

\title{
Malaria's many guises
}

\begin{tabular}{|l|l|l||}
\hline \multicolumn{2}{|c|}{ ArticleInfo } \\
\hline \hline ArticleID & $:$ & 4534 \\
\hline \hline ArticleDOI & $:$ & $10.1186 /$ gb-spotlight-20020719-01 \\
\hline \hline ArticleCitationID & $:$ & spotlight-20020719-01 \\
\hline \hline ArticleSequenceNumber & $:$ & 200 \\
\hline \hline ArticleCategory & $:$ & Research news \\
\hline ArticleFirstPage & $:$ & 1 \\
\hline \hline ArticleLastPage & $:$ & 2 \\
\hline \hline & & RegistrationDate : 2002-7-19 \\
\hline ArticleHistory & $:$ & OnlineDate \\
\hline \hline ArticleCopyright & $:$ & BioMed Central Ltd2002-7-19 \\
\hline \hline ArticleGrants & $:$ & \\
\hline \hline ArticleContext & $:$ & 130593311 \\
\hline \hline
\end{tabular}




\section{Tudor Toma}

Email: t.toma@ic.ac.uk

Understanding the genetic variation of the malarial parasite, Plasmodium falciparum, is of enormous importance in the continued fight against this public health scourge, but the degree of genetic diversity of Plasmodium has been unclear. Two papers in the 18 July Nature, show that P. falciparum is a genetically diverse and complex organism with mechanisms to evade both host immunity and other pharmaceutical antimalarial efforts.

John Wootton and colleagues at the US National Institutes of Health (NIH), Bethesda, Maryland, examined microsatellite markers covering the 14 haploid chromosomes of $P$. falciparum. They observed that the level of genetic diversity varies substantially among different regions of the parasite genome, revealing extensive linkage disequilibrium surrounding the key chloroquine resistance gene (CQR) pfcrt, and at least four CQR founder events (Nature 2002, 418:320-323).

In the second paper, Jianbing $\mathrm{Mu}$ and colleagues, also at $\mathrm{NIH}$, analyzed single nucleotide polymorphisms (SNPs) from 204 genes on chromosome 3 of P. falciparum. They identified 403 polymorphic sites, including 238 SNPs and 165 microsatellites, from five parasite clones, establishing chromosome-wide haplotypes and a dense map with one polymorphic marker per $\sim 2.3$ kilobases. In addition, they estimate the time to the most recent common ancestor to be $\sim 100,000-180,000$ years which coincides with the beginning of the human population expansion (Nature 2002, 418:323-326).

"In principle, $P$. falciparum might rapidly develop resistance to multiple drugs. The genes also seem to have moved across continents with frightening speed, implying that there would be little time to contain the spread of new resistance genes," comments Andrew Clark of Cornell University in an accompanying News and Views article.

\section{References}

1. Wootton JC, Feng J, Ferdig MT, Cooper RA, Mu J,Baruch DI, Magill AJ, Su XZ: Genetic diversity and chloroquine selective sweeps in Plasmodium falciparum. Nature 2002, 418:320-323., [http://www.nature.com]

2. US National Institutes of Health, [http://www.nih.gov/]

3. Mu J, Duan J, Makova KD, Joy DA, Huynh CQ, Branch OH, Li WH, Su XZ:.Chromosome-wide SNPs reveal an ancient origin for Plasmodium falciparum. Nature 2002, 418:323-326., [http://www.nature.com]

4. Cornell University, [http://www.cornell.edu/]

5. Clark AG: Malaria variorum. Nature 2002, 418:283-285., [http://www.nature.com]

This PDF file was created after publication. 